\title{
Mechanical Land Clearing to Promote Establishment of Coastal Sandplain Grassland and Shrubland Communities
}

\author{
Ann L. Lezberg ${ }^{1,3}$ \\ Kendra Buresch ${ }^{2}$ \\ Christopher Neill ${ }^{1,4}$ \\ Tom Chase ${ }^{2}$
}

1. The Ecosystems Center, Marine Biological Laboratory, 7 MBL Street, Woods Hole, MA 02543 U.S.A

2. The Nature Conservancy, Islands Program, RFD 319 X, Vineyard Haven, MA 02568 U.S.A

3. Current Address: Management and Engineering Technologies International, Inc., with USDA Forest Service, Rocky Mountain Research Station, 240 West Prospect, Fort Collins, CO 80526

U.S.A

4. Address correspondence to C. Neill, email cneill@mbl.edu

Correspondence to:

Christopher Neill

The Ecosystems Center

Marine Biological Laboratory,

7 MBL St., Woods Hole, MA, 02543

email: cneill@mbl.edu

phone: (508) 289-7481

Fax: (508) 457-1548

Running title: Land clearing to promote sandplain communities 


\section{Abstract}

The decline in grasslands and other species-rich early-successional habitats on the coastal sandplains of the northeastern U.S. has spurred management to increase the area of these declining plant communities. We mechanically removed overstory oak and applied seed from a nearby sandplain grassland on the island of Martha's Vineyard, Massachusetts to evaluate this technique for creating an open oak community able to support sandplain herbaceous species. We compared vegetation structure and composition before and after clearing in an area of total tree removal (clearcutting), an area where $85 \%$ of tree basal area was removed (savanna cutting) and in adjacent coastal oak forest. Plant responses to clearcutting and savanna cutting were similar. Sandplain herbs colonized at high frequencies after seeding and increasing herbaceous cover from $<7 \%$ before clearing to $22-$ $38 \%$ three growing seasons later. Carex pensylvanica (Pennsylvania sedge) increased in cover 6-fold, accounting for $84-90 \%$ of the increased herbaceous cover. Other native ruderals, and exotic herbs reached $6 \%, 2 \%$, and $\leq 1 \%$, cover respectively, after three years. Species richness across cleared treatments increased from 30 to 79 species. All forest species were retained. Forest shrubs and trees initially declined from their dominant cover, but rebounded after three years. Tree clearing plus seeding appeared to be a viable management practice for increasing cover of herbaceous sandplain species while causing minimal increases in exotic herbaceous cover. The long-term persistence of sandplain herbs may require periodic disturbances that limit woody regrowth. 
IN PRESS

\section{Key words: Carex pensylvanica, Clearcut logging; Coastal oak forest; Coastal sandplain; Conservation and management; Gaylussacia baccata; Heathlands; Sandplain grassland; Massachusetts; New England; Schizachyrium scoparium; Vegetation dynamics.}

\section{Introduction}

The grass- and shrubland habitats of the northeastern coastal sandplain are a conservation priority because of their relative rarity, limited geographical range, and the diversity of uncommon species they support (Dunwiddie et al. 1996; Barbour et al. 1998, MNHESP 2001). These habitats are found only within the coastal outwash plain from Cape Cod, Massachusetts to Long Island, New York with some of the best examples occurring on the offshore islands of Massachusetts, including Nantucket and Martha's Vineyard (Carlson et al. 1991; Motzkin \& Foster 2002). In Massachusetts, coastal sandplain grassland and shrubland communities support 24 species that are listed as endangered, threatened, or of special concern (MNHESP 2004). Today, these habitats are being lost because of rapid regrowth of trees and shrubs in formerly open areas (Dunwiddie 1992, 1994; Dunwiddie \& Adams 1994), fire suppression (Patterson et al. 1983; Dunwiddie \& Adams 1995; Foster \& Motzkin 1999) and rapid residential development (Breunig 2003).

Their limited distribution and high value for regional biodiversity conservation has spurred a wide-ranging discussion of approaches to conserve, manage or expand these habitats. Techniques have included mowing of existing grasslands and low shrublands (Dunwiddie \& Caljouw 1990; Dunwiddie et al. 1997), prescribed burning of grasslands (Niering \& Dreyer 1989; Dunwiddie 1998; Vickery 2002), non-growing season prescribed burning of forest understories (Raleigh et al. 2003; W. A. Patterson, University of Massachusetts, Amherst, MA, 
personal communication), or mechanical removal of trees (Rivers 1997; Foster \& Motzkin 1999). Burning and mowing of existing grasslands have successfully restricted shrub regrowth and resulted in limited increases in some native sandplain plants (Dunwiddie et al. 1997; Dunwiddie 1998; Vickery 2002). But even repeated burning of oak or oak-pine forest understories has not resulted in increased abundance of native plants that more typically occupy open grasslands and shrublands (Parshall et al. 2003; W. A. Patterson, University of Massachusetts, Amherst, MA, personal communication).

Paleoecological data indicate widespread oak-dominated communities in the presettlement New England coastal plain landscape (Ogden 1959, Foster et al. 2002). Many of the larger coastal New England sandplain grasslands that exist today owe their origin to plowing, grazing and other agricultural land uses that expanded after European settlement (Foster et al. 2002). However, the presence of pre-European grass pollen, particularly from Martha's Vineyard, suggests that grasslands or other plant communities that contained a high percentage of grasses, may have been locally important (Stevens 1996; Motzkin \& Foster 2002). The extent, structure, species composition and pre-settlement disturbance regime of these communities are not known but any of these communities would likely have required severe or frequent disturbance, such as tree clearing or growing season fire, for their creation and maintenance.

We describe a manipulation experiment that tested the effectiveness of mechanical tree clearing of oak forest as a management option to increase the area of shrub-grassland suitable for colonization by native sandplain herbaceous plants. Because viable seeds of most herbaceous species were not expected to be available in the seed bank (Matlack \& Good 1990) or from adjacent areas, we followed clearing with distribution of seeds collected from existing sandplain grassland on Martha's Vineyard. Mechanical clearing represents a more severe disturbance than 
the dormant-season fires that have typically been applied in management to encourage recruitment of openland sandplain species into formerly closed forest on the coastal New England outwash plain. Our objectives were: (1) to determine if mechanical clearing followed by seeding would produce an open shrub-grassland community colonized by sandplain herbaceous species while retaining most of the original forest species, and (2) to determine if the clearing and seeding treatments would result in recruitment of ruderal or exotic species that might restrict colonization by native sandplain species or pose future problems for conservation land management. We evaluated the structure and composition of vascular plants for three growing seasons after clearing and seeding. We used the results to make recommendations about the wider application of this management method.

\section{Methods}

\section{Study Site and Experimental Design}

The experiment was conducted on Martha's Vineyard, Massachusetts, an island $8 \mathrm{~km}$ south of Cape Cod, Massachusetts, USA. The 50 -ha research site on Job's Neck $\left(41^{\circ} 21.5^{\prime} \mathrm{N}\right.$, $70^{\circ} 34.7^{\prime} \mathrm{W}$ ) lies 600 to $1300 \mathrm{~m}$ north of the Atlantic coast. The climate is temperate with mean annual precipitation of $1080 \mathrm{~mm}$ distributed evenly throughout the year (Owenby \& Ezell 1992). Soils are deep, excessively drained Typic Udipsamments of the glacial outwash plain (Fletcher \& Roffinoli 1986).

The research site was a 50 to 70 year-old mixed Quercus velutina (black oak) and Quercus alba (white oak) forest white oak with a dense ericaceous shrub layer of Gaylussacia baccata (black huckleberry) and Gaylussacia frondosa (northern dangleberry). Common groundlayer species included Carex pensylvanica (Pennsylvania sedge), Vaccinium angustifolium (lowbush blueberry), Gaultheria procumbens (wintergreen) and Epigaea repens (trailing arbutus). 
Coastal salt spray reaches the site during occasional storms and winds frequently damage tree crowns (Griffiths \& Orians 2003).

Maps from the $19^{\text {th }}$ and $20^{\text {th }}$ century suggest that most of the site was forested throughout modern history with some open areas near the pond shores (U.S. Coast and Geodetic Survey 1848, 1897, Motzkin and Foster 2002). There was no evidence of a plow layer or soil chemistry that would indicate past plowing or presence of past grassland vegetation at this site (Peterson \& Neill 2003). Sandplain grasses and forbs are found on dirt roads or in mowed fields within 0.5 $\mathrm{km}$ of the research site, but were absent from the forest understory prior to treatment.

We divided the research site into areas designated for mechanical clearing and areas to be left unmanipulated as forest controls. Part of the site was clearcut (10.2 ha), part was "savanna cut" ( 9.2 ha) by removing approximately $85 \%$ of tree basal area, and part was left as a control (6.5 ha). Within each area, we established two $100 \mathrm{~m}$ long transects, one in the northern and one in the southern portion. At restricted-random distances along transects, we established 10 perpendicular lines. At random distances along each line we established two (controls) or three (clearcut and savannah cut) permanent $3 \times 3 \mathrm{~m}$ vegetation-sampling plots. In all, 20 lines were established in the control, clearcut and savanna cut areas, with 40 total vegetation plots in the control and 60 total plots in the clearcut and savanna cut areas. Given limitations on land in the coastal sandplain available for experimentation, we chose to create relatively large treatment areas rather than replicate smaller treatments that would not be operationally realistic or at a scale large enough to support a range of sandplain species.

In February 2001, overstory trees in the clearcut and savanna cut areas were harvested near ground level using a feller-buncher and wood was chipped and removed from the site. Shrubs and small trees were mowed with a mechanical brush mower. Oak stump sprouts were 
cut with a mechanical weed brush cutter in summer of 2001 to delay regrowth of oak trees. Seeds from a sandplain grassland at Katama Plain on Martha's Vineyard were harvested in 2001 by dragging a mechanical seed stripper (Prairie Habitats Inc., Model 410i) behind a tractor twice monthly from September through October 2001. The homogenized seed mix was hand-applied to vegetation plots and their $2 \mathrm{~m}$ buffer in the cut treatments within one day of seed harvest.

\section{Vegetation Sampling and Analysis}

In each plot we estimated percent cover of substrate (litter, bare mineral soil, bare organic soil) and cover of live vascular plant species $\leq 2 \mathrm{~m}$ tall in seven cover-abundance classes ( 1 individual, $<1,1-5,6-25,26-50,51-75$, and 76-100\%) (Braun-Blanquet 1965). Nomenclature followed Gleason and Cronquist (1991). Overstory canopy closure was estimated above each plot using a spherical densiometer (Forest Densiometers, Inc.) in four cardinal directions. We also made 120 measurements per treatment with a tube densitometer to quantify the contribution of each tree species to total canopy cover prior to clearing. We estimated leaf area index (LAI) in 2000 for canopy species by quantifying autumn litterfall mass per unit ground area, sorting leaves to species, determining area on individual leaves with a Licor LI-3000 leaf area meter, and relating autumn total leaf mass to LAI.

We sampled from late-July through mid-September when late-season grasses and forbs had reached reproductive maturity. We sampled all plots prior to the clearing treatments, in either 1999 or 2000. These were later combined as the "pre-treatment" period. Control plots were sampled in 2000, 2001 and 2003. The clearcut and savanna cuts were sampled in all years but the north side transects were sampled in 1999, 2001, 2002, and 2003 but the south side transects were not sampled in 2001. 
Species cover classes were transformed to mid-point percent cover values with a value of $0.25 \%$ assigned to the lowest cover class of a single individual. To evaluate structural changes associated with the clearing treatments, we assigned each vascular species to one of six growth forms (understory trees, shrubs, vine, fern, forb, graminoid). Within each plot, mid-point percent cover values of all species were summed to create a composite cover value for that life form. We also measured the height to the nearest $10 \mathrm{~cm}$ of the tallest individual of each tree and shrub species as well as the dominant herb, C. pensylvanica, in each plot beginning in 2001. To compare the response to the treatment of plants with different habitat affinities and origins, we classified all species into four broad groups: native forest species, herbaceous sandplain herbs, native ruderal species, and exotic herbaceous species. Native forest species were those typically associated with coastal oak forest and able to persist for long periods in these relatively open coastal forest understories. Herbaceous sandplain herbs were graminoids and forbs associated with sandplain grasslands on Martha's Vineyard, Nantucket, and Cape Cod (Dunwiddie et al. 1996). Native ruderal species were those considered to be early successional, light-demanding and disturbance-associated species (e.g. Erechtites hieracifolia). Some ruderal shrubs (e.g., Rubus allegheniensis, Comptonia peregrina) persisted at very low frequencies and abundance in the forest understory. Exotic species had origins outside eastern North America.

We averaged the cover values for canopy and substrate, growth forms, habitat groups and individual species within lines, then averaged lines to calculate average cover values for each treatment in each year. We calculated frequency as the proportion of all lines within a treatment in which a measured variable, species group, or species was present. We performed analysis of variance on cover using the GLM procedure of SAS (SAS Institute 2001) with line as the basic sampling unit and treatment and line group (north or south) as the main effects. Separate 
analyses were performed for each year with the assumption that each line was an independent sampling unit. The level of significance was adjusted ( $\alpha$ / no. of comparisons) to account for multiple comparisons (Zar 1984). We used a $\sqrt{ }+0.5$ transform to meet the assumptions of normality and to address the potential for cover values to sum to $>1.00$ (Zar 1984).

\section{Results}

\section{Overstory Structure and Substrate}

The open Q. alba and Q. velutina forest was similar in composition and canopy structure among the control, clearcut and savanna cut prior to manipulation (Table 1). Q. alba and Q. velutina made up $99+\%$ of tree cover in all treatments, total canopy cover ranged from $71-77 \%$ and LAI ranged from 2.59 to $2.98 \mathrm{~m} / \mathrm{m}^{2}$ (Table 1). Prior to manipulation, bare organic and mineral soil were absent and leaf litter covered $\sim 100 \%$ of the ground in all treatments (Fig. 1).

Tree clearing altered soil and canopy structure by reducing canopy cover, increasing the cover of bare organic and mineral soil, and decreasing litter cover (Fig. 1). Overstory canopy cover decreased more in the clearcut than in the savanna cut but remained unchanged in the control (Fig. 1). Overstory canopy remained relatively constant in the clearcut and savanna cut for 3 years after clearing (Fig. 1). Bare organic soil cover increased to $9-11 \%$ in the first growing season after cutting but did not differ between the clearcut and savanna cut (Fig. 1), then decreased to $<1 \%$ after 3 years (Fig. 1). Bare mineral soil cover increased to $2 \%$ in the clearcut and $7 \%$ in the savanna cut in the first growing season after cutting and then decreased to $<2 \%$ after 3 years (Fig. 1). Litter cover decreased to $83-84 \%$ in both cut treatments after one growing season but returned to nearly $100 \%$ after 3 years (Fig. 1). The cover of bare organic soil, bare mineral soil and litter remained unchanged in the control (Fig. 1).

\section{Growth Forms}


Understory tree cover was similar among treatments before the manipulation, decreased in the first growing season after cutting in both the clearcut and the savanna cut, then increased to greater than in the original forest (Fig. 2). Shrub cover was similar among treatments before the manipulations, decreased after cutting, then increased steadily each year but did not return to the level in the original forest after 3 years (Fig. 2). Neither understory tree cover nor shrub cover differed between the clearcut and the savanna cut after 3 years (Fig. 2).

Pretreatment graminoid cover in the clearcut (6\%) exceeded that in the control (1\%) due to uneven distribution of $C$. pensylvanica, but did not differ between the clearcut and the savanna cut (Fig. 2). Graminoid cover increased each year after clearing in the cut treatments and was greater in the clearcut than the savannah (37 vs. $22 \%$ ) after 3 years (Fig. 2). Forb cover was less than graminoid cover but also increased each year after clearing reaching $2 \%$ in both the clearcut and savanna cut after 3 years (Fig. 2). Graminoid and forb cover in the control treatment was near zero and remained constant for three years (Fig. 2).

The height of understory trees in the clearcut and savanna cut treatments was less than in the control treatment during the first growing season after clearing but recovered to the same height as the controls by 2003 (Fig. 3). Shrub height was reduced by clearing and remained less in treated areas than in controls in 2003 (Fig. 3). The height of the dominant herb, $C$. pensylvanica, was greater in the clearcut and savanna cut in all years after clearing (Fig. 3).

\section{Habitat Groups, Individual Species, and Species Richness}

The cover of native forest understory species in the clearcut and savanna cut was similar to the control before cutting, decreased sharply after cutting and then increased steadily to near the level in the control after 3 years (Fig. 4). Native forest species occurred at 100\% frequencies in all years (Fig. 4). Cover of native sandplain herbs increased from 3-6\% in the clearcut and 
savanna cut before cutting to $22 \%$ in the savanna cut and $38 \%$ in the clearcut after 3 years (Fig. 4), but this difference was not statistically significant. The frequency of native sandplain herbs increased to $90 \%$ in the savanna cut and $97 \%$ in the clearcut after 3 years (Fig. 4). Cover of native ruderal species increased from $<1 \%$ to $2 \%$ in the clearcut and savanna cut after 3 years (Fig. 4). Frequency of ruderal species increased to $38 \%$ in the savanna cut and $52 \%$ in the clearcut after 3 years (Fig. 4). There were no exotic herbs in any treatment before the manipulations and cover of exotic herbs remained low, increasing to $0.4 \%$ in the clearcut and $1 \%$ in the savanna cut (Fig. 4). Frequency of exotic herbs, however, was much greater in both cut treatments and increased to $53 \%$ in the clearcut and $80 \%$ in the savanna cut (Fig. 4).

Saplings of the trees Q. alba and Q. velutina and the shrubs G. baccata, G. frondosa, G. procumbens, $V$. angustifolium and E. repens were the dominant native forest understory species before clearing. G. baccata, the most abundant species in all treatments before clearing, remained present in nearly all transects in all years. Although the minor species Toxicodendron radicans (poison ivy) and Q. alba differed prior to clearing, only Q. velutina increased in frequency over time as new stems sprouted from cut trees (Fig. 5). The frequencies of most native forest species changed little over time in the control and cut treatments (Fig. 5).

The clearing treatments increased the frequencies of sandplain herbaceous species (Fig. 6), all of which except $C$. pensylvanica were absent prior to clearing. Prior to clearing, the frequency of C. pensylvanica was already high in the clearcut and savanna cut, but then increased abruptly during the first growing season after clearing (Fig. 6). The cover of $C$. pensylvanica was initially low, but became the largest component of the native sandplain herbaceous cover, rising from $6 \%$ to $35 \%$ cover in the clearcut and $3 \%$ to $19 \%$ cover in the 
savanna cut by 2003. For the majority of sandplain herbaceous species, frequencies increased most in 2002, after planting of seeds in the fall of 2001.

A small number of native ruderal and exotic species increased in frequency in the clearcut and savanna cut after clearing (Fig. 6). Two of these, Pteridium aquilinum (bracken fern) and Rubus allegheniensis (common blackberry) were present at low frequencies before the manipulations. Two minor species (not shown), Pinus rigida (pitch pine) and Juncus tenuis (path rush) were present within $100 \mathrm{~m}$ of the cut areas. The source of Erechtites hieracifolia (pilewort), which reached frequencies of $15 \%$ in the clearcut and $10 \%$ in the savanna cut in 2002 , was not known. Festuca filiformis (hair fescue) was the most important exotic species to colonize the cut treatments and reached peak frequencies of $53 \%$ in the clearcut and $80 \%$ in the savanna cut (Fig. 6). Other exotics present at very low frequencies after clearing included Achillea millifolium var. millifolium (common yarrow), Hypochaeris radicata (cat's ear) and Agrostis canina (velvet bent-grass).

Of the 79 vascular species or taxon identified in all years, 30 were present prior to clearing and 49 were present only in the clearcut and savanna cut after clearing (Table 2). By 2003, the flora included 41 native forest understory species, 22 native sandplain herbs, 12 native ruderal species and 4 exotic herbs (Table 2). These represented 7 trees, 24 shrubs, 3 vines, 1 fern, 26 forbs and 18 graminoid species (Table 2).

Pretreatment species richness was dominated by native forest species (Fig. 7). After clearing, species richness increased in both the clearcut (from 27 to 61 species) and the savanna cut (from 26 to 59 species) (Fig. 7). Increases in sandplain herb diversity (17 to 19 new species) accounted for at least half of this change in both cleared treatments (Fig. 7). All of the 22 species of native sandplain herbs that became established in the clearcut and savanna cut occurred at 
Katama Plain (Table 2). No species listed on the Massachusetts Natural Heritage and Endangered Species Program list of rare, threatened, or special concern species (MNHP 2004) were found.

\section{Discussion}

\section{Vegetation Responses}

Mechanical tree clearing increased plant species richness because no native forest species were eliminated and significant numbers of new species colonized the cleared areas. Despite differences in canopy cover between the clearcut and savanna cut, temporal changes in understory structure and species composition were comparable. The few quantitative differences in species or species group responses (e.g., greater cover of sandplain herbs in clearcut vs savanna) were driven by pretreatment differences in species cover. Clearing followed by seeding appeared to be a viable management strategy for encouraging the establishment of native sandplain herbs while retaining plant species diversity present in the original oak forest.

Twelve of the 14 most abundant sandplain herbs recruited to the plots only in 2002 after seed was distributed. This indicated that seeding was the mechanism for colonization of the cut areas for these species, which included Schizachyrium scoparium (little bluestem grass), three species of goldenrod (Solidago rugosa, S. puberula, S. nemoralis), four species of aster (Aster linariifolius, A. dumosus, A. paternus, A. solidagineus), two species of bent-grasses (Agrostis perennans, A. hyemalis), Euthamia graminifolia (narrow-leaved goldenrod) and Festuca rubra (red fescue). This strongly suggested that seeding is an essential strategy for establishing sandplain herbaceous species during the first three years after mechanical clearing. We cannot absolutely rule out the possibility that seed sources other than the seed from Katama were important and that seed germination time was longer than one year. 
The response of $C$. pensylvanica differed from that of most other native sandplain herbs that colonized after clearing. C. pensylvanica was present at high frequency but low cover prior to clearing, it increased in frequency and cover in 2001 before seeding, and peaked in cover in 2003. This timing suggested that $C$. pensylvanica recruited predominantly by clones during the first growing season after clearing then continued to increase in cover in subsequent years. $C$. pensylvanica possesses both long and short rhizomes, facilitating initial spread and colonization of disturbed and unvegetated areas and subsequent formation of dense sedge mats (Bernard 1990). The high cover of C. pensylvanica after clearing resembled C. pensylvanica-dominated grasslands noted by Dunwiddie et al. (1996). C. pensylvanica is a common component of native grassland and shrubland communities (Dunwiddie et al. 1996), but sedge-dominated grasslands are not generally recognized as a sandplain community type (Swain and Kearsley 2001) and the expanded dominance of C. pensylvanica may be a short-term response to disturbance. However, in the similar sandy nutrient poor jack pine forests of Michigan C. pensylvanica showed similar increases in cover after clearcutting and formed meadows that limited diversity of other understory species (Abrams \& Dickman 1983). The long-term consequences of high $C$. pensylvanica cover are unknown.

Native ruderals and exotic species differed in timing of initial recruitment, suggesting differences in seed sources for these species. All of the common native ruderals recruited into at least some of the plots in 2001 before seeding, indicating a seed source other than from Katama. One common ruderal found at the site, Erechtites hieracifolia, produces wind-dispersed seeds that have been demonstrated to have long-term viability in the soil seed bank (Matlack \& Good 1990; Baskin \& Baskin 1996). The exotic species F. filiformis and A. millefolium var. millefolium were present at Katama but did not recruit to the plots until 2002, suggesting that 
seeding was the mechanism of colonization for these species. Only F. filiformis reached high frequencies in the cleared treatments, suggesting that selection of invasive-free treatment and seed collection sites can avoid problems of invasion when managing to promote native sandplain plants. F. filiformis was present in $47-80 \%$ of sampled lines after 2-3 growing seasons. It is often abundant in coastal Massachusetts grasslands (Dunwiddie et al. 1996), where it closely resembles native red fescue (F. rubra) but it s not suspected to pose a threat to persistence of native sandplain plants. There is little current information about differences in the competitive abilities and life-history traits of native versus exotic sandplain species that could be used to guide management to favor the native sandplain species.

Recruitment patterns following seeding indicate that the mechanical seed stripper successfully collected a large quantity of viable seed from common sandplain species, but may have missed less common species. No recruitment occurred of many less common sandplain herbaceous species that are present at Katama but that are current regional conservation concerns, such as Linum intercursum (sandplain flax), Sisyrinchium fuscatum (sandplain blueeyed grass), Helianthemum dumosum (bushy rockrose) or Liatris scariosa var. novae-angliae (New England blazing star). Seeds of these species may not have been present in the collected seed, or their viability or germination may not have been favored in the post-clearing conditions over three growing seasons.

\section{Relationship to Historic Vegetation}

Oak and mixed oak-pine forest dominated the pre-settlement vegetation of Martha's Vineyard and most of the Massachusetts coastal plain (Ogden 1959; Foster et al. 2002; Eberhardt et al. 2003). European settlement and expansion of cleared land for pastures led to increases in grasses, forbs, shrubs and weed species, created many open grasslands, and strongly shaped the structure of vegetation in areas that were grazed, plowed, burned, or fertilized with manure 
(Foster et al. 2002; Motzkin \& Foster 2002). The abandonment of agriculture beginning as early as 1830 led to an increase in native sandplain herbs for some time on both Martha's Vineyard and Nantucket (Jenkins 1982; Dunwiddie 1994; Motzkin \& Foster 2002). This was followed by a return of dominance of oak and pine-oak forests, a trend in forest area that is now being reversed by intense residential development (Foster et al. 2002; Breunig 2003).

The pre-settlement habitat structure harboring typical native sandplain herbs remains somewhat ambiguous. Modern open sandplain communities have developed on sites ranging from historically plowed land to areas established for fire breaks in predominantly wooded areas (Foster \& Motzkin 1999; Raleigh 2000). These communities, including that which developed in our manipulation, have no definitive pre-settlement analogue (Dunwiddie 2001; Motzkin \& Foster 2002), although they include native species that potentially existed in different combinations before the initiation of European agricultural and other cultural disturbances. Records of pollen in pond sediments from Martha's Vineyard and the Massachusetts coastal plain suggest that species now considered typical of open sandplain grasslands and shrublands were present in the pre-settlement landscape, but were not dominant compared with the oak and pine forest (Stevens 1996; Foster \& Motzkin 1999; Foster and Motzkin 2003). Pre-settlement graminoid pollen was most abundant on outwash deposits, reaching $>10 \%$ in some locations (Stevens 1996; Foster et al. 2002), suggesting the possibility that communities containing graminoids were important in these locations (Sugita et al. 1999; Motzkin \& Foster 2002). These communities may have been present in an open forest, in a mosaic of open grassy patches with oak-shrub or oak-pine woodland, or in areas subjected to frequent disturbances such as overwash, salt spray (Boyce 1954; Griffiths \& Orians 2003), or burning near temporary Native Americans settlements (Patterson \& Sassaman 1988; Motzkin \& Foster 2002). Alternative 
explanations for graminoid pollen on the outwash plain, such as from wetlands along pond edges, also cannot be ruled out.

\section{Management Implications}

Mechanical tree clearing appeared to offer several advantages as a management strategy for expanding the habitat of native sandplain plants on the New England coastal plain. It promoted establishment of a variety of native sandplain species without severe soil disturbance. This is particularly important for areas like Martha's Vineyard, where significant areas were never plowed (Foster \& Motzkin 1999). Mechanical tree clearing avoided the logistical challenges associated with prescribed fire. While mechanical tree clearing followed by seeding created a more open habitat structure, promoted the establishment of a variety of native sandplain grassland herbs and increased overall plant diversity, it did not result in the recruitment of any rare species that are of regional conservation concern. Establishment of these species will likely require more specialized efforts, such as direct collections and sowing of seeds. There are indications that germination of seeds of the sandplain species Liatris scariosa var. novae-angliae is enhanced following fire (Kane \& Schmitt 2001). Information on the seed germination requirements and life history that could guide development of management and reintroduction strategies for these species is limited. Aggressive invasion by exotic species did not appear to be a major management concern if clearing was conducted in oak forests free of existing exotic species and if seed was collected from locations free of highly invasive exotics. Colonization by F. filiformis is potentially unavoidable if seeds of this species are in the distributed seed mixture. Changes to the frequency and cover of $F$. filiformis in relation to native sandplain species should be carefully monitored. Recruitment of some native ruderal and exotic species will potentially always occur with management by clearing and seed distribution because native sandplain herbs 
and ruderal and exotic species are responding to the same post-clearing environmental conditions.

Vigorous sprouting of oaks and the slower regrowth of understory shrubs, particularly the dominant G. baccata, are likely to reduce the abundance of colonizing sandplain herbs if repeated disturbances are not employed to reduce tree and shrub cover (Dunwiddie \& Caljouw 1990; Harper 1995). Occasional prescribed burning, mowing or brush cutting are potential options for restricting oak regrowth. The rapid expansion of C. pensylvanica clones after clearcutting and the subsequent and relatively lower increase in cover of other herbs suggests that C. pensylvanica could also limit establishment, persistence, or spread of a diverse sandplain flora. There were no important differences in plant responses between mechanical removal of all trees and mechanical removal in a savanna cut that left $15 \%$ of tree basal area standing. Less than complete tree removal represents a potential management option that provides roughly equal benefits for native sandplain plant establishment in cases where aesthetic concerns make complete tree removal difficult.

\section{Acknowledgements}

This work was funded by grants from the A. W. Mellon Foundation and the Massachusetts Environmental Trust to MBL and from the Kohlberg Foundation to TNC. We are grateful for the field and logistical assistance provided by Jennifer Alton, Leah Bowe, Julia Brauer, Joel Carlson, Talia Chalew, Michael Dunphy, Rebecca Hale, Bruce Hammond, Richard McHorney, Peter Morgan, Tracy Scanlon, and Ed Schwartzman. Glenn Motzkin and Ernie Steinhauer provided valuable reviews of earlier versions of the manuscript. We express our appreciation to the Kohlberg family for their support and permission to work on their property. 


\section{Literature Cited}

Abrams, M. D., and D. I. Dickmann. 1983. Response of understory vegetation to fertilization on mature and clear-cut jack pine sites in northern Lower Michigan. American Midland Naturalist 110:194-200.

Barbour, H., T. Simmons, P. Swain, and H. Woolsey. 1998. Our irreplaceable heritage. Massachusetts Natural Heritage and Endangered Species Program and The Massachusetts Chapter of the Nature Conservancy. Westborough, MA.

Baskin, C. C., and J. M. Baskin. 1996. Role of temperature and light in the germination ecology of buried seeds of weedy species of disturbed forests. II. Erechtites hieracifolia. Canadian Journal of Botany 74:2002-2005.

Bernard, J. M. 1990. Life history and vegetative reproduction in Carex. Canadian Journal of Botany 68:1441-1448.

Boyce, S. G. 1954. The salt spray community. Ecological Monographs 24:29-67.

Braun-Blanquet, J. 1965. Plant sociology: the study of plant communities. Hafner, London. 439 pp. (Translation by G. D. Fuller and H. S. Conard).

Breunig, K. 2003. Losing ground: at what cost? Changes in land use and their impact on habitat, biodiversity and ecosystem services in Massachusetts. Massachusetts Audubon Society, Lincoln, MA. 25 pp.

Carlson, L., M. Babione, P. J. Godfrey, and A. Fowler. 1991. Ecological survey of heathlands in Cape Cod National Seashore. Botany Department, University of Massachusetts, Amherst. Dunwiddie, P. W. 1992. Changing landscapes: a pictorial field guide to a century of change on Nantucket. Nantucket Conservation Foundation, Nantucket Historical Association and Massachusetts Audubon Society, Nantucket, MA. 
Dunwiddie, P. W. 1994. Martha's Vineyard landscapes: The nature of change. The Vineyard Conservation Society and Peter Dunwiddie, Vineyard Haven, MA.

Dunwiddie, P. W. 1998. Ecological management of sandplain grasslands and coastal heathlands in southeastern Massachusetts. Tall Timbers Fire Ecology Conference Proceedings 20:89-93.

Dunwiddie, P. W. 2001 Using historical data in ecological restoration: a case study from Nantucket. Pages 367-390 in D. Egan and E. A. Howell, editors. The historical ecology handbook: A restorationist's guide to reference ecosystems. Island Press, Washington, D.C. $457 \mathrm{pp}$.

Dunwiddie, P. W., and C. Caljouw. 1990. Prescribed burning and mowing of coastal heathlands and grasslands in Massachusetts. Pages 271-275 in R. S. Mitchell, C. J. Sheviak and D. J. Leopold, editors. Ecosystem management of rare species and significant habitats. Proceedings of the $15^{\text {th }}$ Annual Natural Areas Conference, New York State Museum Bulletin 471 .

Dunwiddie, P. W., and M. A. Adams. 1994. Landscape change on Martha's Vineyard and the Elizabeth Island 1640-1993. The Nature Conservancy, Massachusetts Field Office, Boston, MA.

Dunwiddie, P. W., and M. A. Adams. 1995. Fire suppression and landscape change on outer Cape Cod: 1600-1994. National Park Service Technical Report NPS/EESORNR/NRTR/96-08, Boston, MA.

Dunwiddie, P. W., R. E. Zaremba, and K. A. Harper. 1996. A classification of coastal heathlands and sandplain grasslands in Massachusetts. Rhodora 98:117-145 
Dunwiddie, P. W., W. A. Patterson, III, J. L. Rudnicky, and R. E. Zaremba. 1997. Vegetation management in coastal grasslands on Nantucket Island, Massachusetts: Effects of burning and mowing from 1982 to 1993. Pages 85-98 in P. D. Vickery and P. W. Dunwiddie, editors. Grasslands of northeastern North America: ecology and conservation of native and agricultural landscapes. Massachusetts Audubon Society, Lincoln, MA. 297 p.

Eberhardt, R. W., D. R. Foster, G. Motzkin, and B. Hall. 2003. Conservation of changing landscapes: vegetation and land-use history of Cape Cod National Seashore. Ecological Applications 13:68-84.

Fletcher, P. C., and R. J. Roffinoli. 1986. Soil survey of Dukes County, Massachusetts. U.S. Department of Agriculture, Soil Conservation Service, Washington, D.C.

Foster, D. R., B. Hall, S. Barry, S. Clayden, and T. Parshall. 2002. Cultural, environmental and historical controls of vegetation pattern and the modern conservation setting on the island of Martha's Vineyard, USA. Journal of Biogeography 29:1381-1400.

Foster, D. R., and G. Motzkin. 1999. Historical influences on the landscape of Martha's Vineyard. Harvard Forest Paper No. 23. Harvard Forest, Petersham, MA.

Foster, D. R., and G. Motzkin. 2003. Interpreting and conserving the openland habitats of coastal New England: insights from land use history. Forest Ecology and Management 185:127150.

Gleason, H. A., and A. Cronquist. 1991. Manual of vascular plants of northeastern United States and adjacent Canada. The New York Botanical Garden. 910 p.

Griffiths, M. E., and C. M. Orians. 2003. Salt spray differentially affects water status, necrosis and growth in coastal sandplain heathland species. American Journal of Botany 90:11881196. 
Harper, K. A. 1995. Effect of expanding clones of Gaylussacia baccata (black huckleberry) on species composition in sandplain grassland on Nantucket Island, Massachusetts. Bulletin of the Torrey Botanical Club 122:124-133.

Jenkins, J. 1982. Outline of the vegetation of Nantucket and its recent changes. Center for Environmental Studies, Williams College, Williamstown, MA.

Kane, A., and J. Schmitt. 2001. Liatris borealis Nuttall ex MacNab (Northern Blazing Star) Conservation and Research Plan. New England Wild Flower Society, Framingham, Massachusetts, USA.

Massachusetts Natural Heritage and Endangered Species Program (MNHESP). 2001. Biomapguiding land conservation for biodiversity in Massachusetts. Executive Office of Environmental Affairs, Boston.

Massachusetts Natural Heritage and Endangered Species Program (MNHESP). 2004. Official state rare species list. http://www.mass.gov/dfwele/dfw/nhesp/nhspecies.htm.

Matlack, G. R., and R. E. Good. 1990. Spatial heterogeneity in the soil seed bank of a mature Coastal Plain forest. Bulletin of the Torrey Botanical Club 117:143-152.

Motzkin, G., and D. R. Foster. 2002. Grasslands, heathlands and shrublands in coastal New England: historical interpretations and approaches to conservation. Journal of Biogeography 29:1569-1590.

Niering, W. A., and G. D. Dreyer. 1989. Effects of prescribed burning on Andropogon scoparius in postagricultural grasslands in Connecticut. American Midland Naturalist 122:88-102.

Ogden, J. G., III. 1959. A late-glacial pollen sequence from Martha’s Vineyard, Massachusetts. American Journal of Science 257:366-381. 
Owenby, J. R., and D. S. Ezell. 1992. Monthly Station Normals of Temperature, Precipitation, and Heating and Cooling Degree Days, 1961-1990 (Massachusetts), U.S. Department of Commerce.

Parshall, T., D. R. Foster, E. Faison, D. McDonald, and B. C. S. Hansen. 2003. Long-term vegetation and fire dynamics of pitch-pine-oak forests on Cape Cod, Massachusetts. Ecology 84:736-748.

Patterson, W. A., III, and K. E. Sassaman. 1988. Indian fires in the prehistory of New England, Pages.107-135 in G. P. Nicholas, editor. Holocene human ecology in northeastern North America. Plenum Press, NY.

Patterson, W. A., III, K. E. Saunders, and L. J. Horton. 1983. Fire regimes of Cape Cod National Seashore. U.S. Department of the Interior, National Park Service North Atlantic Region Office of Scientific Studies Report OSS 83-1.

Peterson, G. G., and C. Neill. 2003. Using soil $\delta^{13}$ C to detect the historic presence Schizachyrium scoparium (little bluestem) grasslands on Martha's Vineyard. Restoration Ecology 11:116-122.

Raleigh, L. 2000. Land-use history of Long Point Refuge. The Trustees of Reservations, Vineyard Haven, MA.

Raleigh, L., J. Capece, and A. Berry. 2003. Sand barrens habitat management: a toolbox for managers. The Trustees of Reservations, Vineyard Haven, MA.

Rivers, W. H. 1997. Coming full circle: restoring sand plain grassland communities in the State Forest on Martha's Vineyard, Massachusetts. Pages 79-84 in P. D. Vickery and P. W. Dunwiddie, editors. Grasslands of northeastern North America: Ecology and 
conservation of native and agricultural landscapes. Massachusetts Audubon Society, Lincoln, MA. 297 p.

SAS Institute, Inc. 2001. SAS system for windows. Version 8.02. SAS Institute, Cary, North Carolina.

Stevens, A. 1996. The paleoecology of coastal sandplain grasslands on Martha's Vineyard, Massachusetts. PhD thesis, University of Massachusetts, Amherst.

Swain, P. C., and J. B. Kearsley. 2001. Classification of the Natural Communities of Massachusetts. Natural Heritage and Endangered Species Program, Massachusetts Division of Fisheries and Wildlife, Westborough, MA.

Sugita, S. J., J. Gaillard, and A. Brostrom. 1999. Landscape openness and pollen records: a simulation approach. Holocene 9:409-421.

U.S. Coastal and Geodetic Survey. 1848. Maps of Martha's Vineyard, Massachusetts. Marine Biological Laboratory Archives, Woods Hole, MA.

U.S. Coastal and Geodetic Survey. 1897. Maps of Martha's Vineyard, Massachusetts. Marine Biological Laboratory Archives, Woods Hole, MA.

Vickery, P. D. 2002. Effects of the size of prescribed fire on insect predation of northern blazing star, a rare grassland perennial. Conservation Biology 16:413-431.

Zar, J. H. 1984. Biostatistical analysis. Prentice Hall, NY, $2^{\text {nd }}$ edition. 


\section{Figure Legends}

Figure 1. Changes to mean overstory canopy closure and the cover of bare organic soil, bare mineral soil and leaf litter before and after clearing manipulations. Symbols are $(\bullet)$ control; $(\diamond)$ clearcut; $(\Delta)$ savanna cut. Error bars are \pm 1 se. Different letters indicate significant differences among treatments in each year, $\mathrm{p} \leq 0.05$. Overstory canopy closure was estimated as the mean of four spherical densiometer readings above each plot.

Figure 2. Changes to mean cover of understory trees, shrubs, graminoids and forbs before and after clearing manipulations. Symbols are as in Figure 2. Error bars are \pm 1 se. Different letters indicate significant differences among treatments in each year, $\mathrm{p} \leq 0.05$.

Figure 3. Changes to mean height of understory trees, shrubs and the abundant sedge, Carex pensylvanica after clearing manipulations. Symbols are as in Figure 2. Error bars are \pm 1 se. Different letters indicate significant differences among treatments in each year, $\mathrm{p} \leq 0.05$.

Figure 4. Changes to mean cover (left column) and frequency (right column) of native forest understory species, native sandplain herbs, native ruderal herbs and shrubs and exotic herbs before and after the clearing manipulations. Symbols are $(\bullet)$ control; $(\diamond)$ clearcut; $(\Delta)$ savanna cut. Error bars for cover are \pm 1 se. Different letters for cover indicate significant differences among treatments in each year. 
Figure 5. Frequency of important native forest understory species before and after clearing manipulations. Species that did not exceed a threshold of a frequency of at least $20 \%$ in one treatment in one year are not shown. Symbols are $(\bullet)$ control; $(\diamond)$ clearcut; $(\Delta)$ savanna cut.

Figure 6. Frequency of native sandplain herbs, native ruderal herbs and exotic species before and after clearing manipulations. Species that did not exceed a threshold of a frequency of at least 10 $\%$ in one treatment in one year are not shown. Symbols are $(\bullet)$ control; $(\diamond)$ clearcut; $(\Delta)$ savanna cut.

Figure 7. Species richness of native forest species, ruderal herbs and shrubs, sandplain herbs, and exotic herbs counted across all plots for each treatment before and after the clearing manipulations. Sixty plots were sampled in each cleared treatment, while 40 plots were sampled in the control treatments. 


\section{Table Legends}

Table 1. Tree cover and leaf area index (LAI) in 2000 before manipulations. Cover is the percentage of tube densitometer readings taken under each species or summed among species to give total cover.

Table 2. Species present in all $3 \times 3$ plots from 1999-2003. Species were classified into growth form and habitat-life history groups, whether they were present before the manipulations, present only after the manipulations and whether they were present in the grassland at Katama Plain $(*)$ where seeds were collected. Life history classifications were: native forest species (NF), native ruderal species (NR), exotic species (E) and native sandplain herbaceous species (NSH). 
Table 1. Tree cover and leaf area index (LAI) in 2000 before manipulations. Cover is the percentage of tube densitometer readings taken under each species or summed among species to give total cover.

\begin{tabular}{lcccccc}
\hline & \multicolumn{2}{c}{ Quercus alba } & \multicolumn{2}{c}{ Quercus velutina } & Total & Total \\
& Cover & LAI & Cover & LAI & Cover & LAI \\
Treatment & $\%$ & $\mathrm{~m}^{2} / \mathrm{m}^{2}$ & $\%$ & $\mathrm{~m}^{2} / \mathrm{m}^{2}$ & $\%$ & $\mathrm{~m}^{2} / \mathrm{m}^{2}$ \\
\hline Control & 28 & 0.70 & 43 & 1.83 & 71 & 2.59 \\
Clearcut & 33 & 1.06 & 43 & 1.71 & 77 & 2.79 \\
Savanna cut & 41 & 1.67 & 33 & 1.30 & 74 & 2.98 \\
\hline
\end{tabular}


Table 2. Species present in all $3 \times 3$ plots from 1999-2003. Species were classified into growth form and habitat-life history groups, whether they were present before the manipulations, present only after the manipulations and whether they were present in the grassland at Katama Plain $(*)$ where seeds were collected. Life history classifications were: native forest species (NF), native ruderal species (NR), exotic species (E) and native sandplain herbaceous species (NSH).

\begin{tabular}{|c|c|c|c|c|}
\hline Species & $\begin{array}{l}\text { Growth form } \\
\text { classification }\end{array}$ & $\begin{array}{l}\text { Life history } \\
\text { classification }\end{array}$ & $\begin{array}{c}\text { Present before } \\
\text { clearing }\end{array}$ & $\begin{array}{l}\text { Present only } \\
\text { after clearing }\end{array}$ \\
\hline Quercus alba & Tree & $\mathrm{NF}$ & $\mathrm{X}$ & \\
\hline Quercus stellata & Tree & $\mathrm{NF}$ & $\mathrm{X}$ & \\
\hline Quercus velutina & Tree & $\mathrm{NF}$ & $\mathrm{X}$ & \\
\hline Pinus rigida* & Tree & NR & & $\mathrm{X}$ \\
\hline Amelanchier sp.* & Tree & $\mathrm{NF}$ & $\mathrm{X}$ & \\
\hline Salix discolor & Tree & $\mathrm{NF}$ & & $\mathrm{X}$ \\
\hline Prunus serotina* & Tree & NF & $\mathrm{X}$ & \\
\hline Quercus ilicifolia* & Shrub & $\mathrm{NF}$ & $X$ & \\
\hline Aronia melanocarpa/prunifolia* & Shrub & $\mathrm{NF}$ & $\mathrm{X}$ & \\
\hline Corylus cornuta & Shrub & $\mathrm{NF}$ & $\mathrm{X}$ & \\
\hline Gaylussacia baccata* & Shrub & $\mathrm{NF}$ & $\mathrm{X}$ & \\
\hline Ilex verticillata & Shrub & $\mathrm{NF}$ & $\mathrm{X}$ & \\
\hline Viburnum dentatum* & Shrub & $\mathrm{NF}$ & $\mathrm{X}$ & \\
\hline Viburnum nudum* & Shrub & $\mathrm{NF}$ & & $\mathrm{X}$ \\
\hline Gaylussacia frondosa* & Shrub & $\mathrm{NF}$ & $\mathrm{X}$ & \\
\hline Kalmia angustifolium* & Shrub & $\mathrm{NF}$ & $\mathrm{X}$ & \\
\hline
\end{tabular}




\begin{tabular}{|c|c|c|c|}
\hline Lyonia ligustrina & Shrub & NF & $\mathrm{X}$ \\
\hline Rhododendron viscosum & Shrub & NF & $\mathrm{X}$ \\
\hline Vaccinium corymbosum* & Shrub & NF & $\mathrm{X}$ \\
\hline Vaccinium pallidum* & Shrub & NF & $\mathrm{X}$ \\
\hline Rosa carolina* & Shrub & NF & \\
\hline Rubus allegheniensis* & Shrub & NR & $\mathrm{X}$ \\
\hline Rhus copallinum* & Shrub & NR & \\
\hline Myrica pensylvanica* & Shrub & $\mathrm{NF}$ & $\mathrm{X}$ \\
\hline Quercus prinoides* & Shrub & NF & \\
\hline Rubus hispidus* & Shrub & NF & $\mathrm{X}$ \\
\hline Toxicodendron radicans* & Shrub & NF & $\mathrm{X}$ \\
\hline Epigaea repens & Shrub & NF & $\mathrm{X}$ \\
\hline Gaultheria procumbens & Shrub & NF & $\mathrm{X}$ \\
\hline Vaccinium angustifolium* & Shrub & $\mathrm{NF}$ & $\mathrm{X}$ \\
\hline Comptonia peregrina* & Shrub & NR & \\
\hline Vitis labrusca* & Vine & $\mathrm{NF}$ & \\
\hline Parthenocissus quinquefolia* & Vine & NF & $\mathrm{X}$ \\
\hline Smilax glauca & Vine & NF & $\mathrm{X}$ \\
\hline Pteridium aquilinum & Fern & NR & $\mathrm{X}$ \\
\hline Anemone quinquefolia & Forb & $\mathrm{NF}$ & $\mathrm{X}$ \\
\hline Lysimachia quadrifolia & Forb & $\mathrm{NF}$ & \\
\hline Prenanthes trifoliolata & Forb & $\mathrm{NF}$ & \\
\hline Melampyrum lineare* & Forb & $\mathrm{NF}$ & $\mathrm{X}$ \\
\hline
\end{tabular}




\begin{tabular}{|c|c|c|c|}
\hline Monotropa uniflora & Forb & NF & \\
\hline Ambrosia artemisiifolia & Forb & NR & \\
\hline Conyza canadensis & Forb & NR & \\
\hline Erechtites hieraciifolia & Forb & NR & \\
\hline Hypericum sp.* & Forb & NR & \\
\hline Phytolacca americana & Forb & $\mathrm{NR}$ & \\
\hline Polygonum punctatum var. punctatum & Forb & NR & \\
\hline Achillea millefolium var. millefolium* & Forb & $\mathrm{E}$ & \\
\hline Hypochaeris radicata & Forb & $\mathrm{E}$ & \\
\hline Anaphalis margaritacea* & Forb & $\mathrm{NSH}$ & \\
\hline Aster linariifolius* & Forb & $\mathrm{NSH}$ & \\
\hline Baptisia tinctoria* & Forb & $\mathrm{NSH}$ & \\
\hline Euthamia graminifolia* & Forb & $\mathrm{NSH}$ & \\
\hline Euthamia tenuifolia* & Forb & $\mathrm{NSH}$ & \\
\hline Helianthemum propinquum* & Forb & $\mathrm{NSH}$ & \\
\hline Lechea maritima* & Forb & $\mathrm{NSH}$ & \\
\hline Aster dumosus* & Forb & $\mathrm{NSH}$ & \\
\hline Aster paternus* & Forb & $\mathrm{NSH}$ & \\
\hline Aster solidigineus* & Forb & $\mathrm{NSH}$ & \\
\hline Solidago nemoralis* & Forb & $\mathrm{NSH}$ & \\
\hline Solidago puberula* & Forb & $\mathrm{NSH}$ & \\
\hline Solidago rugosa* & Forb & $\mathrm{NSH}$ & \\
\hline Carex pensylvanica* & Graminoid & $\mathrm{NSH}$ & $\mathrm{X}$ \\
\hline
\end{tabular}


Luzula multiflora*

Festuca rubra*

Juncus tenuis*

Agrostis perennans*

Agrostis canina

Festuca filiformis*

Danthonia spicata*

Juncus greenei*

Panicum sp. *

Panicum virgatum*

Schizachyrium scoparium*

Deschampsia flexuosa*

Agrostis hyemalis*

Carex swanii

Cyperus sp.

Juncus effuses

Carex cf. cumulata (Ovina group)
Graminoid NF

X

Graminoid NSH

Graminoid NR

Graminoid NSH

Graminoid E

Graminoid E

Graminoid NSH

Graminoid NSH

Graminoid NSH

Graminoid NSH

Graminoid NSH

Graminoid NF

Graminoid NSH

Graminoid NF

Graminoid NF

Graminoid NF

Graminoid NF
X

$\mathrm{X}$

X

$\mathrm{X}$

X

$\mathrm{X}$

X

$\mathrm{X}$

$\mathrm{X}$

X

$\mathrm{X}$

X

X

X

X

X 

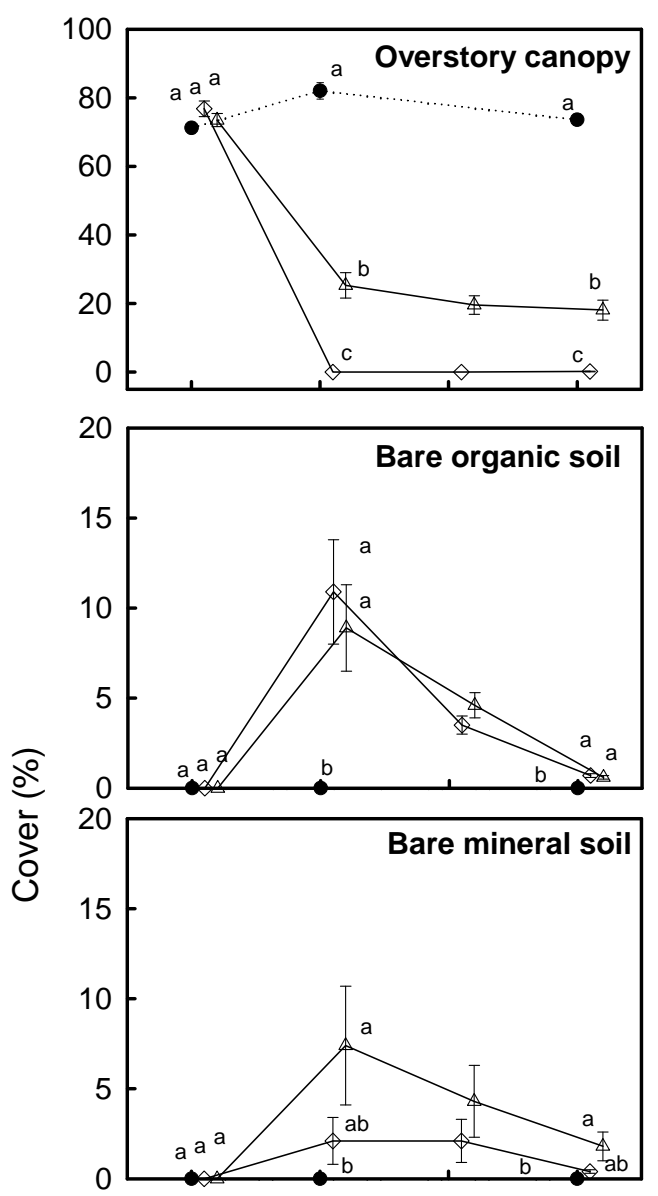

Figure 1

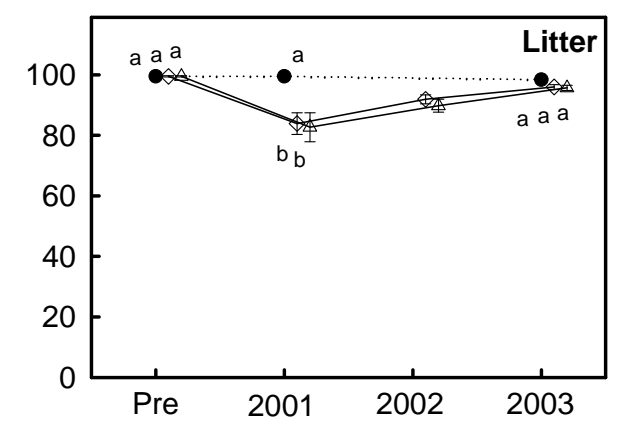


Figure 2

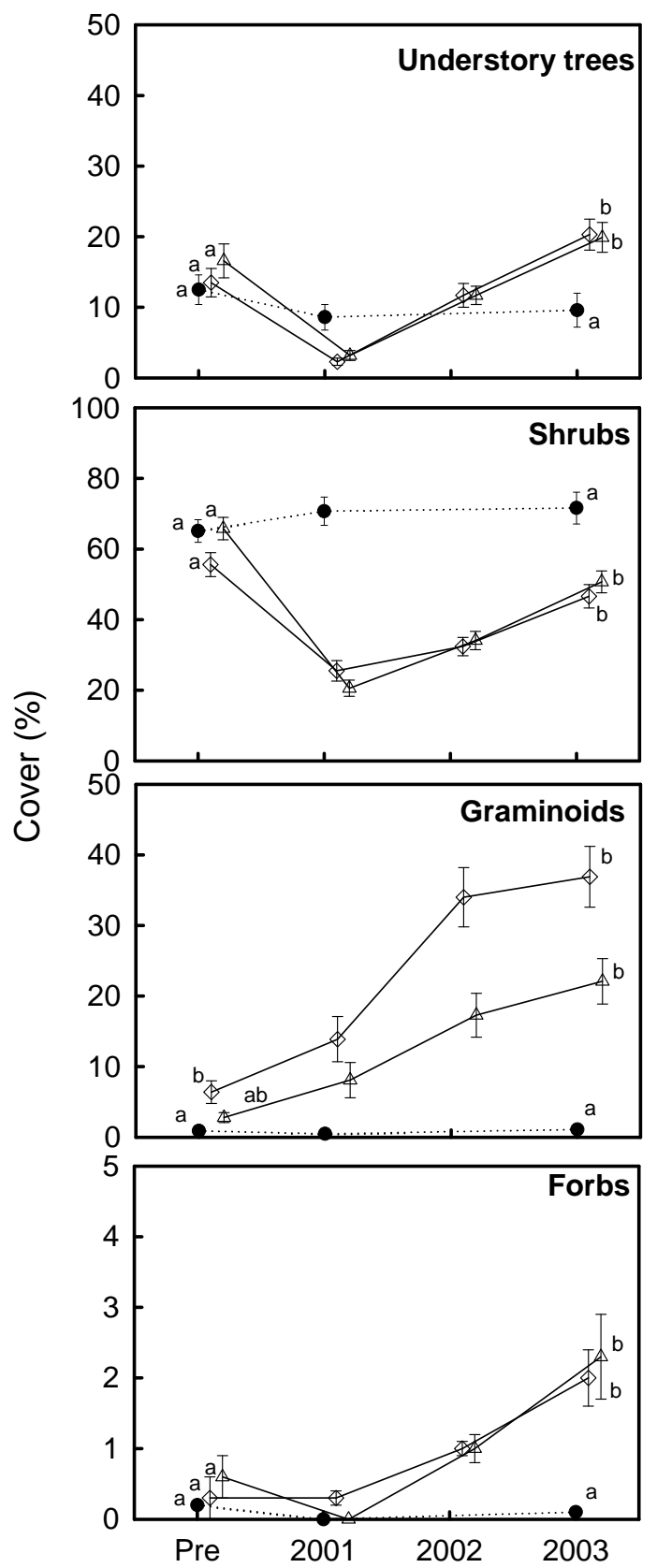




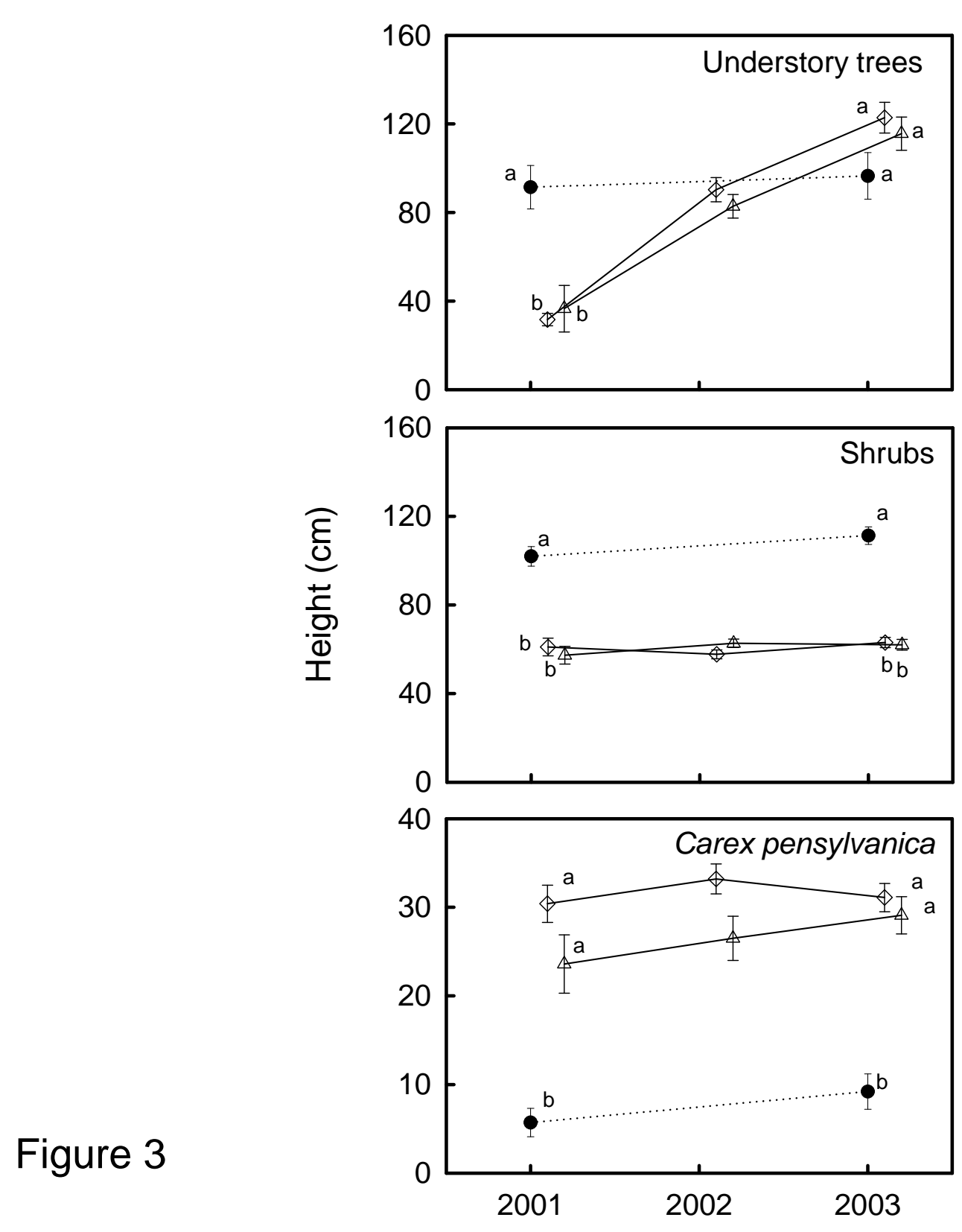



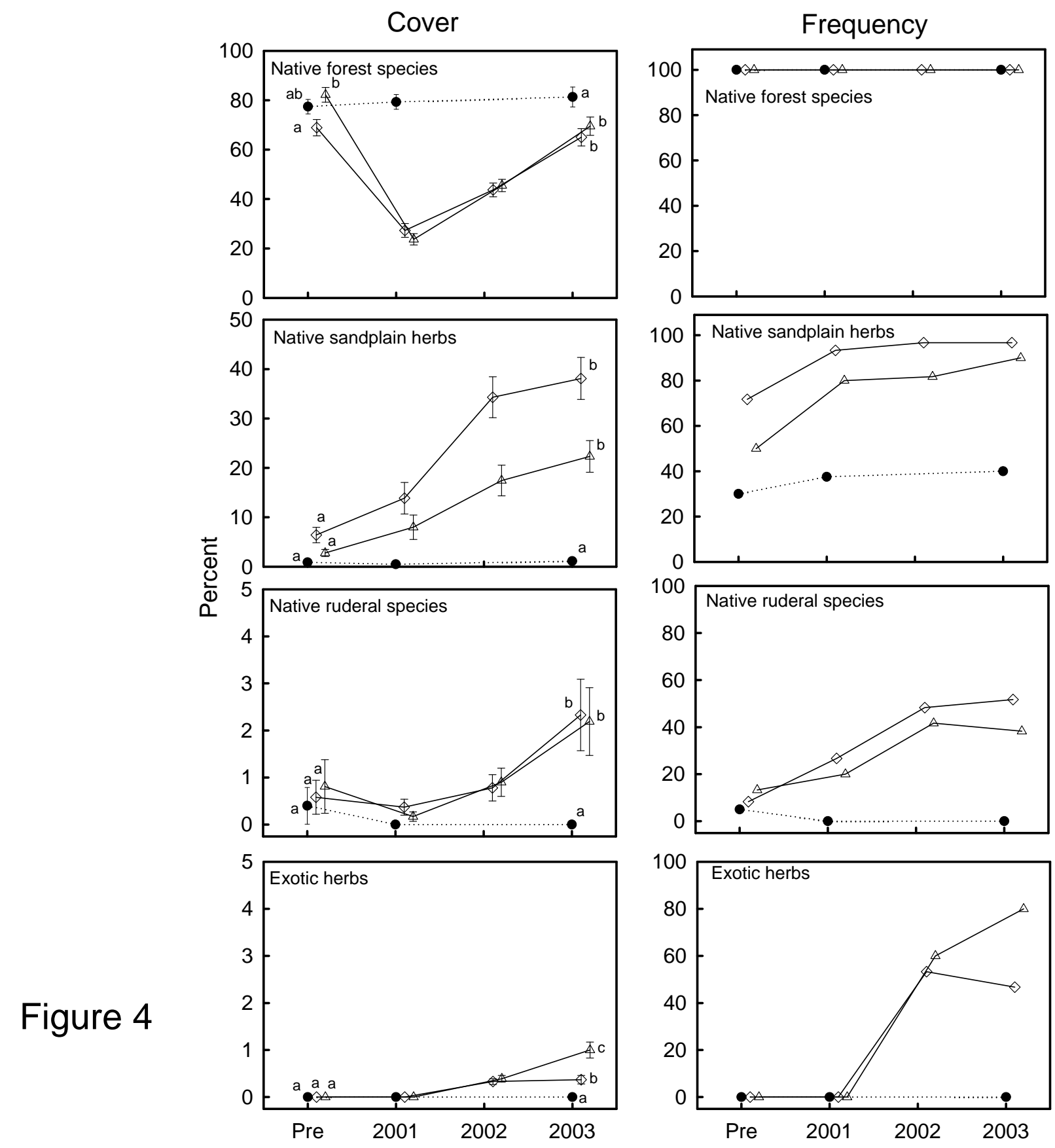

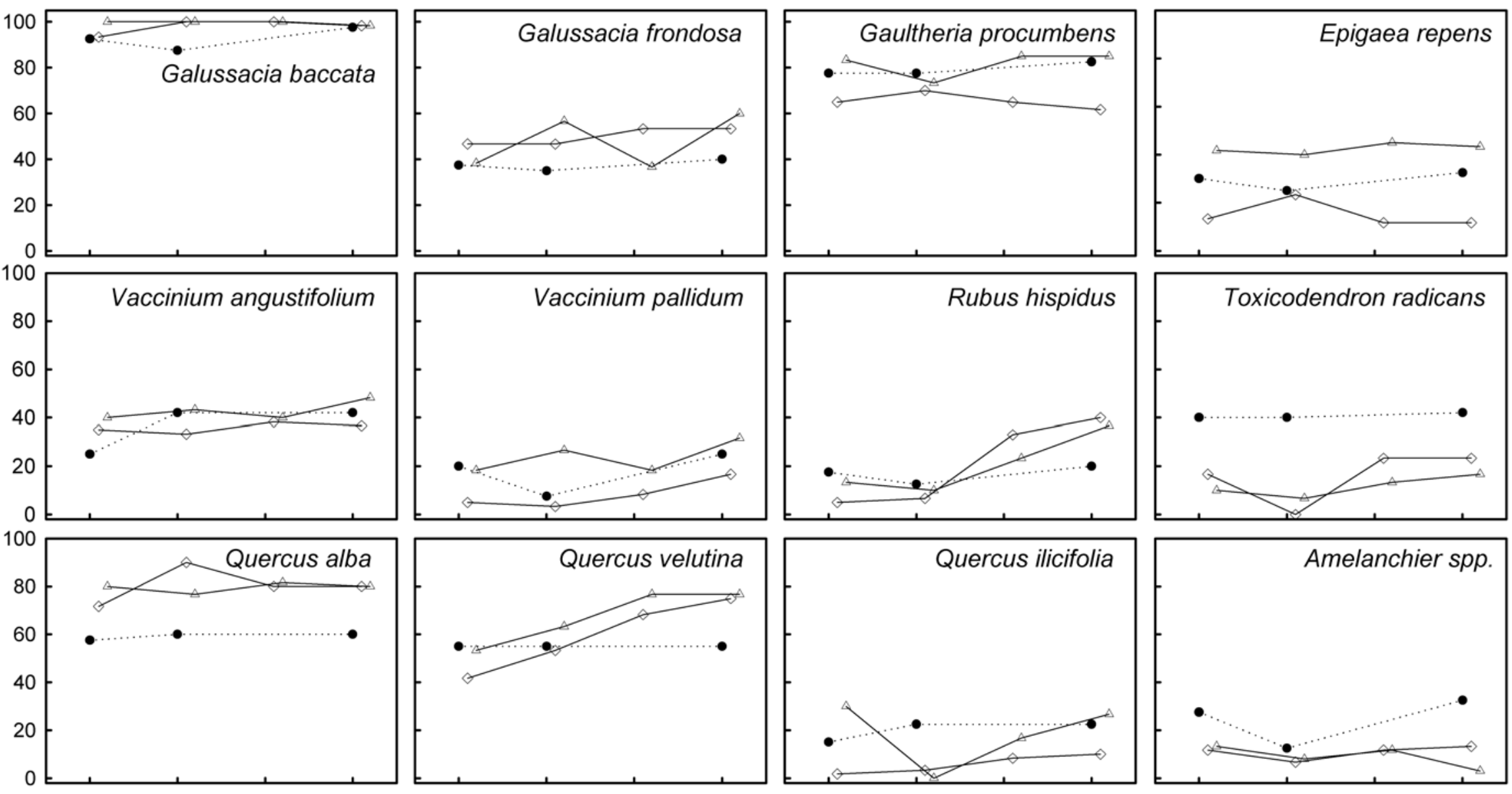

Pre $2001 \quad 2002 \quad 2003$

Pre $20012002 \quad 2003$

Pre $2001 \quad 2002 \quad 2003$

Pre $2001 \quad 2002 \quad 2003$

Figure 5 
Native Sandplain Herbs

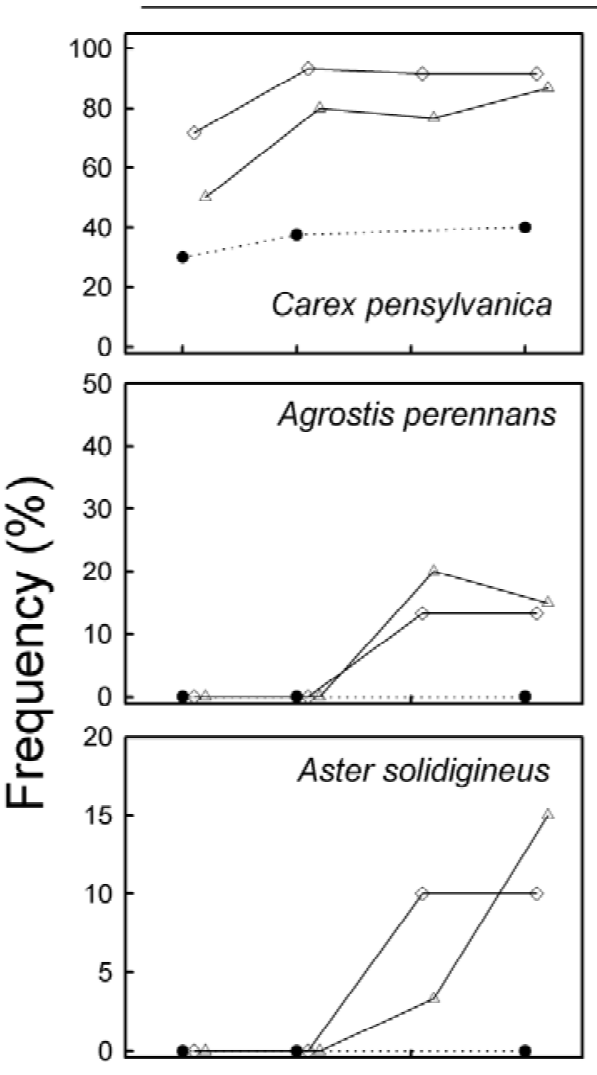

Figure 6
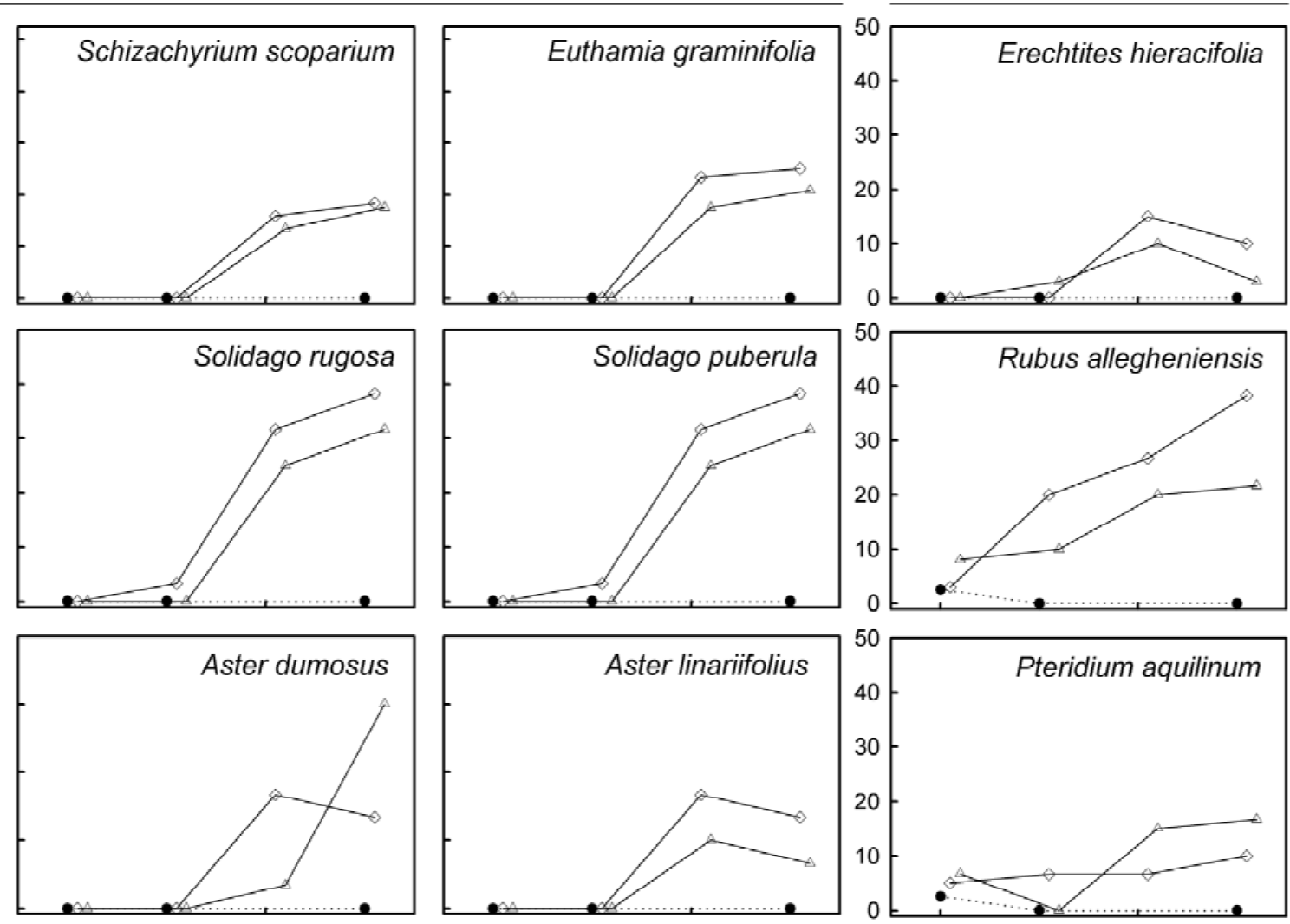

Exotic Species
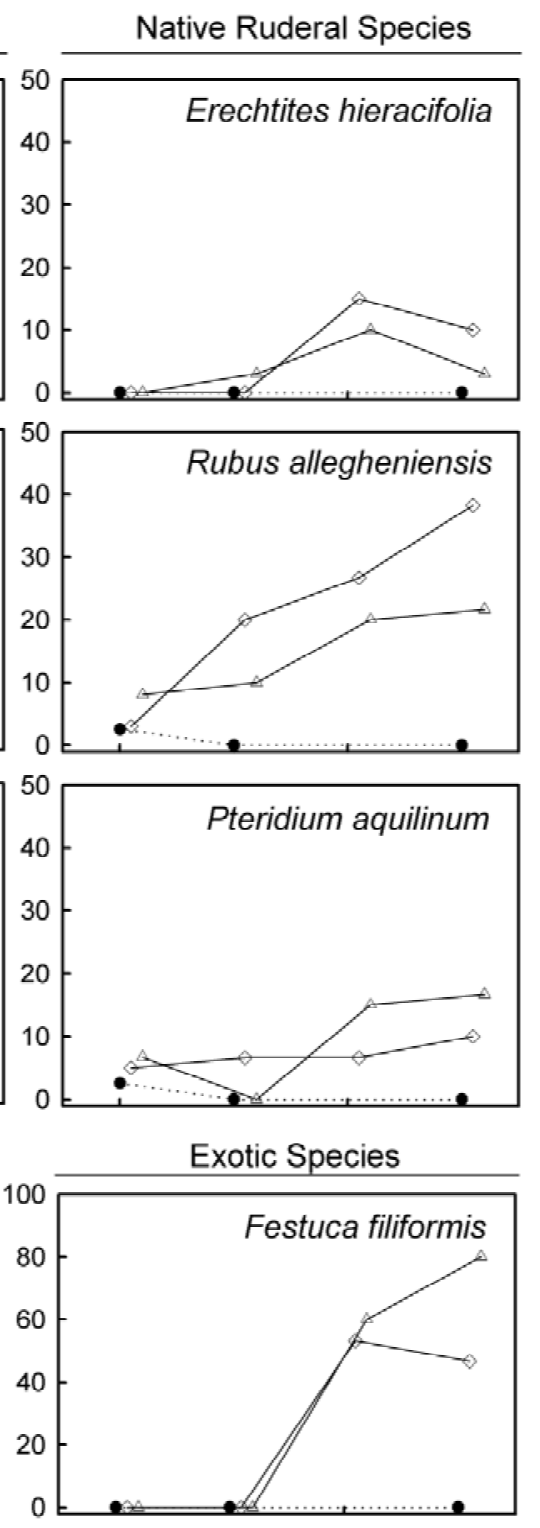

Figure 6.

REC-04-146.R2

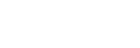




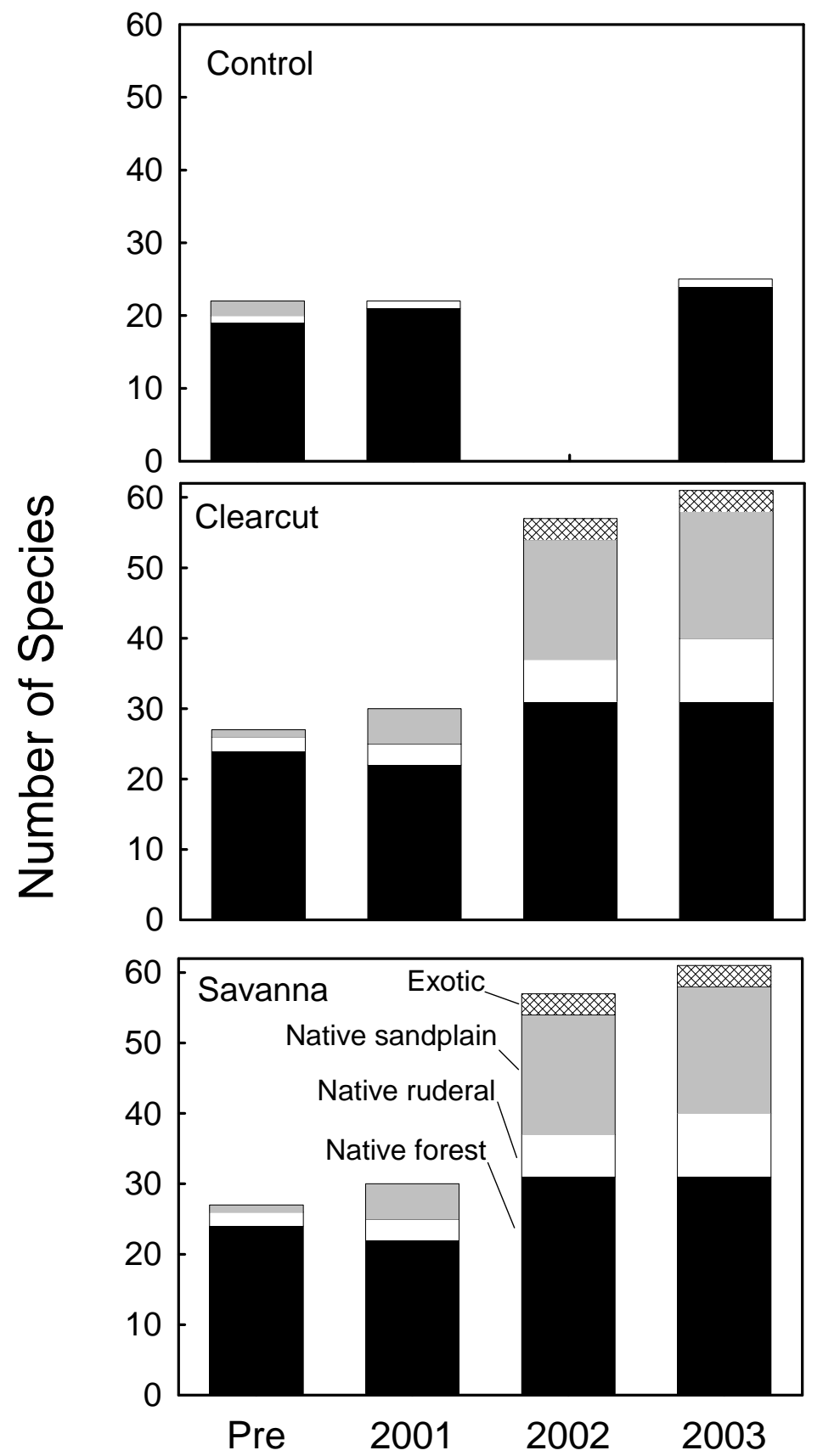

